\title{
THE INFLUENCE OF BAKING TIME AND TEMPERATURE ON CHARACTERISTICS OF GLUTEN FREE COOKIES ENRICHED WITH BLUEBERRY POMACE
}

\author{
Bojana M. Šarić, Nataša M. Nedeljković, Olivera D. Šimurina, Mladenka V. Pestorić, Jovana J. Kos, \\ Anamarija I. Mandić, Marijana B. Sakač, Ljubiša Ć. Šarić, Đorđe B. Psodorov, Aleksandra Č. Mišan \\ University of Novi Sad, Institute of Food Technology, 21000 Novi Sad, \\ Bulevar cara Lazara 1, Serbia
}

\author{
*Corresponding author: \\ Phone: +381214853837 \\ Fax: +38121450725 \\ E-mail address: bojana.saric@fins.uns.ac.rs
}

\begin{abstract}
Blueberry pomace, by-product of juice production, was processed into a new food ingredient by drying and grinding and used for a new gluten-free cookies' formulation, with the aim of improving nutritional profile and antioxidant capacity. Since duration and temperature at which dough is thermally treated during baking highly influence the quality of a baked product, the objective of this work was to optimise the baking conditions in order to obtain the best technological quality of the cookies.

Referring to the results obtained at 160 and $170{ }^{\circ} \mathrm{C}$ and different baking times, the following was found: the difference in baking conditions caused variation between cookies' diameters of less than $1 \%$, more regular shape of the cookies was obtained when baking time was shorter, hardness of cookies is highly correlated with moisture content, water activity, baking loss and short/long diameter ratio values. The colour characteristics $\left(L^{*}, a^{*}\right.$ and $\left.b^{*}\right)$ of cookies' top and bottom surfaces indicated that the cookies were not overbaked under the chosen baking conditions.

Baking time of 14 min at $170{ }^{\circ} \mathrm{C}$ was found to be the optimal baking conditions for the blueberry pomace enriched gluten-free cookies.
\end{abstract}

Key words: gluten-free cookies, blueberry pomace, baking time, baking temperature

\section{INTRODUCTION}

Blueberries are a rich source of anthocyanins and other antioxidant compounds, which may have health-promoting effects (Prior et al., 1998). As blueberries have a limited shelf life, a large portion of fresh blueberries is processed into juice. The juice processing generates a large quantity of pomace which consists of skins, pulp residue, and seeds. It is usually treated as a waste product (Bener et al., 2013). However, the pomace can be processed into a new food ingredient by simply drying and grinding it to reduce the coarse texture.
Celiac disease represents life-long intolerance to the gliadin fraction of wheat and the prolamins or rye (secalins), barley (hordeins) and possibly oats (avenin). Gluten is a protein which possesses structureforming ability that affects elastic properties of dough and contributes to the overall appearance and crumb structure of many baked products. Production of high-quality gluten-free products represents a signifycant technological challenge as the removal of gluten in gluten-free formulation represents a very demanding task which often results in low quality, poor mouth feel 
and low flavour products (Torbica et al., 2012).

Consumers adhered to gluten-free diet more and more require gluten-free foods that resemble traditional ones. As a consequence, in recent years, there has been an extensive research for the development of gluten-free sweet bakery products with improved structure, mouth feel, acceptability, shelf-life and nutritional quality of the final products (Matos et al., 2014). Not only gluten-free, cookies in general are products of relatively poor nutritional quality because they contain mainly starchy ingredients.

With an aim of improving nutritional and antioxidant capacity of gluten-free cookies by, at the same time, revalorization of blueberry juice-production by-products, the pomace, which was previously dried and ground, was used to substitute a part of the gluten-free mixture to obtain a new gluten-free formulation.

As expected, by substituting a part of a gluten-free mixture, dough properties were significantly changed and a product with different properties was obtained. It is known that the quality of cookies is highly influenced by its composition and by a number of different parameters at the production line (Walker et al., 2012).

Baking time and temperature highly influence heat transfer and the quality of a baked product, due to complex physicchemical interactions that occur between the ingredients, leading to the difference, primarily in texture, aroma and color of the products (Shibukawa et al., 1989).

Referring to all above mentioned, the main objective of this work was to optimize the baking process of new blueberry pomace gluten-free cookies in order to achieve the best technological quality.

\section{MATERIAL AND METHODS}

\section{Materials}

Fresh blueberry pomace was obtained as a by-product from the juice production line at "Zdravo Organic", Selenča, Serbia. After drying in a dry heat sterilizer (Instrumentaria, Zagreb) at $40{ }^{\circ} \mathrm{C}$, until the water activity value $\left(a_{w}\right)$ of 0.3 was reached, the pomace was ground in a laboratory mill (KnifetecTM 1095 mill, Foss, Hoganas, Sweden) and the fraction passing through the $0.80 \mathrm{~mm}$ sieve was used for further analysis.

Gluten-free mixture consisting of: corn starch, corn flour, potato starch, potato flour, rice flour, guar gum, baking powder and salt was obtained from "Nutri Allergy Center", Zemun, Serbia.

Vegetable fat, powdered eggs, sugar and glucose syrup were commercially available.

\section{Cookies preparation}

Gluten-free cookies in which $30 \%(\mathrm{w} / \mathrm{w})$ of gluten-free mixture was substituted with dried blueberry pomace were prepared according to the recipe given in Table 1 . All ingredients were weighed together and mixed for $10 \mathrm{~min}$ in Farinograph mixing bowl (Brabender, Germany) tempered at $30{ }^{\circ} \mathrm{C}$. The obtained dough was kept for $24 \mathrm{~h}$ at $8{ }^{\circ} \mathrm{C}$. Thirty minutes before the processing, dough was tempered at the room temperature $\left(20{ }^{\circ} \mathrm{C}\right)$. Pilot scale dough sheeter (Mignon, Italy) was used to sheet the dough to $6 \mathrm{~mm}$ thickness. The dough was cut into round shapes of 50 $\mathrm{mm}$ diameter, placed on a baking tray and baked in a laboratory oven (MIWE Gusto ${ }^{\circledR}$ CS, Germany). Baking temperature was firstly set at $170{ }^{\circ} \mathrm{C}$ and four batches of cookies (Table 2 ) were obtained by changing baking time (10, 13, 14 and $16 \mathrm{~min})$. Afterwards, the baking temperature was set at $160{ }^{\circ} \mathrm{C}$ and two additional batches of cookies were obtained (at baking time 16 and $17 \mathrm{~min}$ ). All batches were prepared using $150 \mathrm{~g}$ of gluten-free mixture. Two separate batches of cookies were prepared for all combinations of baking time and temperature. The obtained gluten-free cookies were cooled down at room temperature for $2 \mathrm{~h}$ and stored in sealed polypropylene bags until analysis.

\section{Determination of baking quality of cookies}

AACC baking quality method (AACC 1050D, 1999) was used for determination of width $(\mathrm{W})$, thickness $(\mathrm{T}), \mathrm{W} / \mathrm{T}$ ratio (cookie spread factor) and short/long ratio (S/L). 
Table 1.

Cookies' baking formulation

\begin{tabular}{lc}
\hline Ingredient & $\begin{array}{c}\text { Gluten-free mixture base } \\
(\%)\end{array}$ \\
\hline Gluten-free mixture & 70 \\
Blueberry pomace & 30 \\
Sugar & 35 \\
Glucose syrup & 16 \\
Vegetable fat & 18 \\
Powdered egg & 2 \\
Water & 36 \\
\hline
\end{tabular}

Table 2.

Cookies' baking conditions

\begin{tabular}{ccc}
\hline Cookie & $\begin{array}{c}\text { Temperature } \\
\left({ }^{\circ} \mathbf{C}\right)\end{array}$ & Time $(\min )$ \\
\hline 1 & 170 & 10 \\
2 & 170 & 13 \\
3 & 170 & 14 \\
4 & 170 & 16 \\
5 & 160 & 16 \\
6 & 160 & 17 \\
\hline
\end{tabular}

Six cookies from each batch were measured giving a total of 12 measurements for each combination of baking time and temperature. In order to describe the deviation from the ideally round shape, long and short diameter were measured and their ratio was calculated. These parameters were measured using digital calliper (Carl Roth, Germany).

\section{Colour evaluation of cookies}

Colour measurements of cookies' top and bottom surfaces were carried out $24 \mathrm{~h}$ after baking. These measurements were performed on 12 cookies for each combination of baking conditions using a Minolta Chroma Meter CR-400 (Sensing Inc., Japan) colorimeter. The obtained results were expressed in terms of $L^{*}$ (lightness), $a^{*}$ (redness/greenness) and $b^{*}$ (yellowness/blueness) values.

\section{Textural characteristics of cookies}

Textural analysis of the cookies was conducted using a TA.XTPlus Texture Analyzer (Stable Micro Systems, England, UK), equipped with a 3-point bending rig (HDP/3PB), and a $30 \mathrm{~kg}$ load cell. Texture analyzer settings were: mode - measure force in compression; pre-test speed -1.0 $\mathrm{mm} / \mathrm{s}$; test speed $-3.0 \mathrm{~mm} / \mathrm{s}$; post-test speed - $10.0 \mathrm{~mm} / \mathrm{s}$; distance - 5.0 $\mathrm{mm}$; trigger force - $50 \mathrm{~g}$. Textural properties were determined $24 \mathrm{~h}$ after baking and the obtained results were expressed as the hardness value.

\section{Water activity and moisture determination}

Prior to water activity $\left(\mathrm{a}_{\mathrm{w}}\right)$ and moisture determination, cookies were ground and sieved to $0.8 \mathrm{~mm}$ particle size using laboratory mill (KnifetecTM 1095 mill, Foss, Hoganas, Sweden).

Water activity was determined using Testo 650 measuring instrument with a pressuretight precision humidity probe (Testo AG, USA). Each result presents the average value of 3 measurements.

Moisture content of cookies was determined according to AOAC (2000) method.

\section{Baking weight loss}

Baking weight loss (BWL) was determined by measuring the cookie weight before and after baking. It was calculated according to the equation:

BWL $(\%)=\left(m_{0}-m_{t}\right) / m_{0}^{*} 100$

where $\mathrm{m}_{0}$ was initial cookie weight $(\mathrm{g})$; $\mathrm{m}_{\mathrm{t}}$ was the weight $(\mathrm{g})$ after baking time $\mathrm{t}$ (min). 
Cookies weight $\left(m_{0}\right.$ and $\left.m_{t}\right)$ was determined as average value of 8 independent measurements.

\section{Sensory evaluation of cookies}

In order to evaluate the quality cookies produced by different baking conditions, sensory assessment was performed. Quality ratings of cookies were performed by a team of experts from the Institute of Food Technology, Novi Sad, Serbia. Since all of them were highly familiar with this type of products and their production processes, the observed samples were evaluated in relation to their overall quality, including primary and relevant sensory attributes (appearance, texture and flavour). Experts were asked to rate and recommend the cookie of best quality using a 5-point scale from $1=$ not likely to $5=$ very likely. The order of presentation of the samples was randomized and the samples were coded with the random three-digit numbers. Each sample was evaluated twice and an average value was taken.

\section{RESULTS AND DISCUSSION}

Baking is a complex process which results in a series of physical, chemical and biochemical changes in the product (Sablani et al., 1998). Physically, it is a process involving the simultaneous heat and mass transfer phenomena, and both baking time and temperature are industrially important process considerations affecting the final quality (Fahloul et al., 1994; Sablani et al., 1998). Dimensions and moisture content changes of cookies are considered to be important parameters of cookie quality, since the large variability in these parameters may cause breakdown (cracking, checking, etc) problems (Cronin and Preis, 2000). Typical baking temperatures for fibre enriched cookies are in the range of $160-180{ }^{\circ} \mathrm{C}$ (depending on the type of oven) with a baking time between 7 and 16 minutes (Manley, 1998).

In our experiment, two temperatures (160 and $170{ }^{\circ} \mathrm{C}$ ) were chosen on the basis of previous experience in baking of gluten free cookies using the experimental oven. Baking quality results of the cookies are summarized in Table 3. Cookies 1-4 ob- tained at the baking temperature of $170{ }^{\circ} \mathrm{C}$ and different baking times had diameter values which were not significantly different $(p<0.05)$. Similar results were obtained for the cookies produced at the baking temperature of $160{ }^{\circ} \mathrm{C}$ (cookies 5 and 6 ), indicating that the baking time did not affect the width of the cookies. Referring to the experiment as a whole, the difference in baking conditions caused variation between the diameters of less than $1 \%$.

However, in regard to the $S / L$ at the temperature of $170^{\circ} \mathrm{C}$, significant differences existed between the samples baked for 10 min and those baked for 13, 14 and 16 min, which pointed out that more oval cookies (higher $\mathrm{S} / \mathrm{L}$ value) were obtained when baking time was shorter. The S/L values of cookies baked at $160{ }^{\circ} \mathrm{C}$ were not significantly different $(p<0.05)$ from those obtained at $170{ }^{\circ} \mathrm{C}$ for $16 \mathrm{~min}$.

Spread factor (W/T) was significantly higher for cookies baked at $160^{\circ} \mathrm{C}$ in comparison to those baked at $170{ }^{\circ} \mathrm{C}$. Since diameter values for all cookies were similar, changes in spread factor between cookies were caused by the differences in cookies' thickness $(\mathrm{T})$.

The lowest value of thickness and the highest $\mathrm{W} / \mathrm{T}$ ratio was obtained for cookies baked for 17 minutes, probably due to the highest vapour and gas loss, which caused cookie spreading and deformation (the lowest $S / L)$.

The overall quality of bakery products is dependent on chemical, biochemical, physical, rheological and structural changes (volume expansion, evaporation of water, starch gelatinization, protein denaturation, aroma compound formation) which occur during baking (Thorvaldson and Janestad, 1999), which are highly influenced by changes of moisture content as a function of process parameters (time and temperature). Therefore, another important factor that affects the quality of cookies is the moisture content (Manley, 1998). Equilibrium moisture of cookies is usually ranged from 3 to $5 \%$ while cookies of a special type may contain up to $7 \%$ moisture (Manley, 2000). 
Table 3.

Baking quality of gluten free cookies enriched with blueberry pomace: width (W), thickness (T), W/T ratio and ratio between short and long diameter $(\mathrm{S} / \mathrm{L})$

\begin{tabular}{ccccc}
\hline Cookie & $\mathbf{W}(\mathbf{m m})$ & $\mathbf{T}(\mathbf{m m})$ & $\mathbf{W} / \mathbf{T}$ & $\mathbf{S} / \mathbf{L}$ \\
\hline $\mathbf{1}$ & $51.31 \pm 0.06^{\mathrm{a}}$ & $8.04 \pm 0.05^{\mathrm{a}}$ & $6.38 \pm 0.03^{\mathrm{a}}$ & $0.983 \pm 0.00^{\mathrm{c}}$ \\
$\mathbf{2}$ & $51.29 \pm 0.14^{\mathrm{a}}$ & $8.05 \pm 0.03^{\mathrm{a}}$ & $6.38 \pm 0.03^{\mathrm{a}}$ & $0.966 \pm 0.01^{\mathrm{b}}$ \\
$\mathbf{3}$ & $51.30 \pm 0.10^{\mathrm{a}}$ & $8.05 \pm 0.03^{\mathrm{a}}$ & $6.41 \pm 0.03^{\mathrm{a}}$ & $0.962 \pm 0.00^{\mathrm{b}}$ \\
$\mathbf{4}$ & $51.29 \pm 0.08^{\mathrm{a}}$ & $8.16 \pm 0.02^{\mathrm{d}}$ & $6.29 \pm 0.02^{\mathrm{b}}$ & $0.937 \pm 0.01^{\mathrm{a}}$ \\
$\mathbf{5}$ & $51.41 \pm 0.05^{\mathrm{a}, \mathrm{b}}$ & $7.67 \pm 0.03^{\mathrm{c}}$ & $6.71 \pm 0.04^{\mathrm{c}}$ & $0.942 \pm 0.01^{\mathrm{a}}$ \\
$\mathbf{6}$ & $51.60 \pm 0.16^{\mathrm{b}}$ & $7.55 \pm 0.06^{\mathrm{b}}$ & $6.84 \pm 0.07^{\mathrm{d}}$ & $0.932 \pm 0.01^{\mathrm{a}}$ \\
\hline
\end{tabular}

Different letters in the same column indicate significant differences $(p<0.05)$ between mean values according to the Duncan's range test

Although the most uniform shape of cookies was obtained for the shortest baking time (10 $\mathrm{min})$, these baking conditions could not be chosen as optimal since the obtained cookies had moisture content of $10.03 \pm 0.04 \%$.

Water activity is a measure of food dryness and susceptibility of a product to microbial spoilage. The components of blueberry pomace (sugar and pectin) as well as guar gum from gluten free mixture bind the water making it less available for microbial growth (Einhorn-Stoll et al., 2012).

The results of $\mathrm{a}_{\mathrm{w}}$ and moisture content in cookies baked at different conditions indicate the significant influence of baking temperature and time on these parameters (Table 4). The lowest $a_{w}$ value and moisture content were obtained in cookies baked for 17 minutes at $160{ }^{\circ} \mathrm{C}$ and cookies baked 16 minutes at $170{ }^{\circ} \mathrm{C}$. These results are highly correlated with the results of cookies weight loss during baking. However, cookies obtained at the temperature of $170{ }^{\circ} \mathrm{C}$ baked for 10 min were susceptible to yeasts and moulds growth due to their high $a_{w}$ value. Although correlation between the total moisture content and $a_{w}$ of a food is often reported (as in this study) this correlation does not occur at all times (Zamora et al., 2006).

Instrumentally measured, the hardness of cookies was expressed as a maximum force necessary to break them. When it is sensory estimated, the hardness is a force required to bite the cookie. Textural characteristics of cookies are one of the most important quality parameters governing consumers' acceptance. The highest value of this parameter was obtained in cookies characterized by the longest baking time while cookies baked 10 minutes at $170{ }^{\circ} \mathrm{C}$ had the lowest value of hardness. Textural properties of cookies baked at the following baking conditions: $13 \mathrm{~min}$ at $170{ }^{\circ} \mathrm{C}$, $14 \mathrm{~min}$ at $170{ }^{\circ} \mathrm{C}$ and $16 \mathrm{~min}$ at $160{ }^{\circ} \mathrm{C}$ were not significantly different $(p<0.05)$.

Hardness of cookies is highly correlated with the moisture content, $a_{w}$, baking loss and $S / L$ values (Table 5 ). Apart from the baking conditions, the type and quantity of the ingredients used for the product manufacture have been known to highly influence its hardness and other textural characteristics. According to Pyler (1988), ingredient used can be categorized by its functional role, for example shortening is a tenderizer, flour is a toughener and egg proteins help build a stable cell structure.

Significant positive correlation existed between following parameters: moisture/ $\mathrm{a}_{\mathrm{w}}$; moisture/S/L ratio; $a_{w} / S / L$ ratio as well as a negative correlation between baking loss and moisture/ $\mathrm{a}_{\mathrm{w}}$. The colour characteristics $\left(L^{*}, a^{*}\right.$ and $\left.b^{*}\right)$ of cookies' top surfaces were dependant on baking conditions (Table 6). Increase in the temperature and duration of the thermal treatment led to increase in redness $\left(\mathrm{a}^{*}\right)$ and lightness $\left(\mathrm{L}^{*}\right)$.

With the increase in baking time $L^{*}$ value increased, probably due to higher vapour loss during baking, which indicated that cookies were not over baked and that Maillard reaction and caramelization did not occur to extend to negatively influence the colour formation (Chung et al., 2014).

Colour characteristics $\left(L^{*}, a^{*}\right.$ and $\left.b^{*}\right)$ of the top and bottom surface of cookies were significantly different $(p<0.05)$. 


\section{Table 4.}

Gluten free cookies enriched with blueberry pomace: water activity, moisture content, baking weight loss and hardness

\begin{tabular}{ccccc}
\hline Cookie & $\mathbf{a}_{\mathbf{w}}$ & Moisture (\%) & Baking weight loss $(\%)$ & Hardness $(\mathbf{g})$ \\
\hline $\mathbf{1}$ & $0.60 \pm 0.00^{\mathrm{e}}$ & $10.03 \pm 0.04^{\mathrm{e}}$ & $10.26 \pm 0.36^{\mathrm{d}}$ & $894.4 \pm 104.2^{\mathrm{b}}$ \\
$\mathbf{2}$ & $0.43 \pm 0.00^{\mathrm{a}}$ & $6.68 \pm 0.01^{\mathrm{a}}$ & $14.36 \pm 0.22^{\mathrm{e}}$ & $3265.5 \pm 140.8^{\mathrm{a}}$ \\
$\mathbf{3}$ & $0.43 \pm 0.00^{\mathrm{a}}$ & $6.64 \pm 0.04^{\mathrm{a}}$ & $15.44 \pm 0.20^{\mathrm{a}}$ & $3465.1 \pm 409.5^{\mathrm{a}}$ \\
$\mathbf{4}$ & $0.36 \pm 0.00^{\mathrm{c}}$ & $5.76 \pm 0.02^{\mathrm{c}}$ & $15.88 \pm 0.03^{\mathrm{b}, \mathrm{c}}$ & $4824.1 \pm 232.3^{\mathrm{c}}$ \\
$\mathbf{5}$ & $0.41 \pm 0.00^{\mathrm{d}}$ & $6.15 \pm 0.02^{\mathrm{d}}$ & $15.63 \pm 0.31^{\mathrm{a}, \mathrm{b}}$ & $3522.8 \pm 222.1^{\mathrm{a}}$ \\
$\mathbf{6}$ & $0.32 \pm 0.00^{\mathrm{b}}$ & $5.12 \pm 0.01^{\mathrm{b}}$ & $16.15 \pm 0.10^{\mathrm{c}}$ & $5378.9 \pm 410.3^{\mathrm{d}}$ \\
\hline
\end{tabular}

Different letters in the same column indicate significant differences $(p<0.05)$ between mean values according to the Duncan's range test

Table 5.

Correlations between cookies parameters obtained at different baking time and temperatures

\begin{tabular}{cccccccc}
\hline & $\mathbf{S} / \mathbf{L}$ & $\mathbf{H}(\mathbf{g})$ & $\mathbf{B W L}(\%)$ & $\mathbf{M}(\%)$ & $\mathbf{a}_{\mathbf{w}}$ & $\mathbf{T}(\mathbf{m m})$ & $\mathbf{W} / \mathbf{T}$ \\
\hline $\mathbf{H}(\mathbf{g})$ & $-0.8680^{*}$ & & & & & & \\
$\mathbf{B W L}(\%)$ & $-0.8208^{*}$ & $0.9095^{*}$ & & & & & \\
$\mathbf{M}(\%)$ & $0.8019^{*}$ & $-0.9501^{*}$ & $-0.9714^{*}$ & & & & \\
$\mathbf{a}_{\mathbf{w}}$ & $0.8656^{*}$ & $-0.9728^{*}$ & $-0.9551^{*}$ & $0.9811^{*}$ & & & \\
$\mathbf{T}(\mathbf{m m})$ & $0.5125^{*}$ & -0.3868 & -0.3590 & 0.3302 & 0.4270 & & \\
$\mathbf{W} / \mathbf{T}$ & $-0.5333^{*}$ & 0.4120 & 0.3810 & -0.3581 & -0.4467 & $-0.9962^{*}$ & \\
$\mathbf{W}(\mathbf{m m})$ & -0.4027 & 0.3735 & 0.3817 & -0.4063 & -0.3619 & $-0.5182^{*}$ & $0.5889^{*}$ \\
\hline
\end{tabular}

Marked correlations $\left(^{*}\right)$ are significant at $\mathrm{p}<0.05$

$\mathrm{S} / \mathrm{L}$ - short/long ratio; H (g) - hardness; BWL (\%) - baking weight loss; M (\%) - moisture; $\mathrm{a}_{\mathrm{w}}$ - water activity; T $(\mathrm{mm})$ - thickness; W/T - cookie spread factor; W $(\mathrm{mm})$ - width

Table 6.

Colour parameters $\left(\mathrm{L}^{*}, \mathrm{a}^{*}\right.$ and $\left.\mathrm{b}^{*}\right)$ of cookies' top and bottom surfaces

\begin{tabular}{ccccccc}
\hline & \multicolumn{3}{c}{ Top surface } & \multicolumn{3}{c}{ Bottom surface } \\
\hline & $\mathbf{L}^{*}$ & $\mathbf{a}^{\star}$ & $\mathbf{b}^{\star}$ & $\mathbf{L}^{*}$ & $\mathbf{a}^{*}$ & $\mathbf{b}^{*}$ \\
\hline 1 & $30.45 \pm 0.46^{\mathrm{a}}$ & $17.42 \pm 0.38^{\mathrm{a}}$ & $2.47 \pm 0.09^{\mathrm{c}}$ & $25.77 \pm 1.40^{\mathrm{a}}$ & $15.19 \pm 0.25^{\mathrm{b}}$ & $2.63 \pm 0.17^{\mathrm{a}}$ \\
2 & $31.16 \pm 0.83^{\mathrm{a}}$ & $17.41 \pm 0.32^{\mathrm{a}}$ & $2.18 \pm 0.07^{\mathrm{a}}$ & $25.60 \pm 0.40^{\mathrm{b}}$ & $14.48 \pm 0.32^{\mathrm{a}}$ & $3.46 \pm 0.47^{\mathrm{b}}$ \\
3 & $32.58 \pm 0.33^{\mathrm{b}}$ & $17.46 \pm 0.36^{\mathrm{a}, \mathrm{b}}$ & $2.23 \pm 0.11^{\mathrm{a}}$ & $24.72 \pm 0.78^{\mathrm{a}}$ & $14.49 \pm 0.68^{\mathrm{a}}$ & $2.56 \pm 0.23^{\mathrm{a}}$ \\
4 & $32.51 \pm 0.34^{\mathrm{b}}$ & $17.99 \pm 0.62^{\mathrm{b}, \mathrm{c}}$ & $2.03 \pm 0.08^{\mathrm{b}}$ & $27.35 \pm 0.65^{\mathrm{b}}$ & $13.96 \pm 0.62^{\mathrm{a}}$ & $3.32 \pm 0.63^{\mathrm{b}, \mathrm{c}}$ \\
5 & $31.17 \pm 0.43^{\mathrm{a}}$ & $17.58 \pm 0.20^{\mathrm{a}, \mathrm{b}}$ & $2.20 \pm 0.09^{\mathrm{a}}$ & $25.65 \pm 1.03^{\mathrm{a}}$ & $14.23 \pm 0.29^{\mathrm{a}}$ & $2.89 \pm 0.23^{\mathrm{a}, \mathrm{c}}$ \\
6 & $32.82 \pm 0.63^{\mathrm{b}}$ & $18.14 \pm 0.32^{\mathrm{c}}$ & $2.28 \pm 0.02^{\mathrm{a}}$ & $27.31 \pm 0.97^{\mathrm{b}}$ & $14.20 \pm 0.39^{\mathrm{a}}$ & $3.47 \pm 0.24^{\mathrm{b}}$ \\
\hline
\end{tabular}

Different letters in the same column indicate significant differences $(p<0.05)$ between mean values according to the Duncan's range test

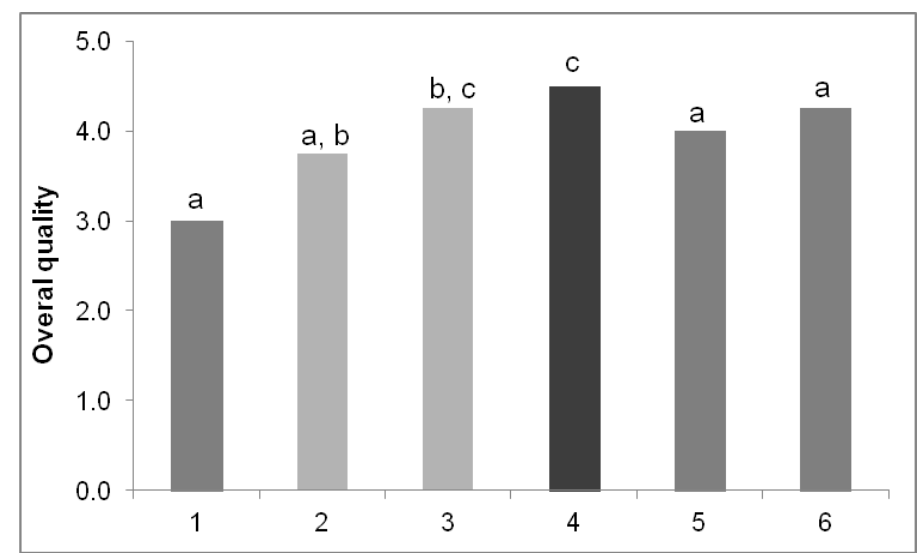

Figure 1. Gluten free cookies enriched with blueberry pomace: mean values of overall sensory quality 
The bottom surface is characterized by lower $L^{*}$ and $a^{*}$ values and higher $b^{*}$ values. However colour evaluation of cookies during their sensory evaluation indicate that cookies' bottom surfaces were not over baked.

The mean values of overall sensory quality are shown in Fig 1. As the expert panel had a well-defined concept of cookies' quality in their evaluation, the samples were sorted into two groups $(p<0.05)$. Sample 4 , obtained by baking at $170{ }^{\circ} \mathrm{C}$ was found to be of the best acceptability. However, regarding the fact that sample 3 had more regular shape ( $\mathrm{S} / \mathrm{T}$ value) and hardness, and that it was similarly scored by the panel, baking time of $14 \mathrm{~min}$ at 170 ${ }^{\circ} \mathrm{C}$ could be considered optimal for the blueberry pomace enriched gluten-free cookies in the previously mentioned type of oven.

\section{CONCLUSIONS}

Blueberry pomace, after drying and grinding can be used as an ingredient for the production of gluten-free cookies. Baking conditions, temperature and baking time were found to highly influence the properties of the final product. Baking time of $14 \mathrm{~min}$ at $170{ }^{\circ} \mathrm{C}$ could be considered optimal for the blueberry pomace enriched gluten-free cookies production under the given experimental conditions.

\section{ACKNOWLEDGEMENTS}

This study was supported by the Provincial Secretariat for Science and Technological Development of the Autonomous Province of Vojvodina, Project No. 114-4514684/2013-03.

\section{REFERENCES}

1. AACC 10-50D (1999). Approved methods of the American Association of Cereal Chemists (edition no. 10), Minnesota, USA

2. AOAC (2000). Official methods of analysis of AOAC international, W. Horwitz (ed. no. 17), Maryland, USA

3. Bener, M. Shen, Y. Apak, R. Finley, J. W., Xu, Z. (2013). Release and degradation of anthocyanins and phenolics from blueberry pomace during thermal acid hydrolysis and dry heating, Journal of Agricultural and Food Chemistry, 61(27), 6643-6649.
4. Chung, H. J., Cho, A., Lim, S. T. (2014). Utilization of germinated and heat-moisture treated brown rices in sugar-snap cookies, LWT - Food Science and Technology, in press, http://dx.doi.org/10.1016/j.Iwt.2014.01.018.

5. Cronin, K., Preis, C. (2000). A statistical analysis of biscuit physical properties as affected by baking, Journal of Food Engineering, 46, 217-225.

6. Einhorn-Stoll, U. Hatakeyama, H., Hatakeyama, T. (2012). Influence of pectin modification on water binding properties, Food Hydrocolloids, 27, 494-502.

7. Fahloul, D., Trystram, G., Duquenoy, A., Barbotteau, I. (1994). Modeling heat and mass transfer in band oven biscuit baking, Lebensmittel Wissenchauft und Technologie, 27, 119-124.

8. Manley, D. (1998). Manual for Baking and Cooling of Biscuits, Woodhead Publishing Limited, Abington, Cambridge, England.

9. Manley, D. (2000). Technology of Biscuits, Crackers, and Cookies, Woodhead Publishing Limited, Third edition, England.

10. Matos, M. E., Sanz, T., Rosell, C. M. (2014). Establishing the function of proteins on the rheological and quality properties of rice based gluten free muffins, Food Hydrocolloids, 35, 150-158.

11. Pyler E. J. (1988). Baking Science and Technology, Sosland Publishing, Merriam, Kansas.

12. Prior, R. L., Cao, G., Martin, A., Sofic, E., McEwen, J., O'Brien, C., Lischner, N., Ehlenfeldt, M., Kalt, W., Krewer, G., Mainlend, C. M. (1998). Antioxidant capacity as influenced by total phenolics and anthocyanin content, maturity and variety of Vaccinium species, Journal of Agricultural and Food Chemistry, 46, 2668- 2693.

13. Sablani, S.S., Marcotte, M., Baik, O.D., Castaigne, F. (1998). Modeling of simultaneous heat and water transport in the baking process, Lebensmittel Wissenchauft und Technologie, 31, 201-209.

14. Shibukawa, S., Sugiyama, K., Yano, T. (1989). Effects of heat-transfer by radiation and convection on browning of cookies at baking, Journal of Food Science, 54 (3), 621-624.

15. Thorvaldson, K., Janestad, H. (1999). A model for heat, water and vapour diffusion. Journal of Food Engineering, 40, 167-172.

16. Torbica, A., Hadnađev, M., Dapčević Hadnađev, T. (2012). Rice and buckwheat flour characterisation and its relation to cookie quality, Food Research International, 48(1), 277-283.

17. Walker, S., Seetharaman, K. Goldstein, A. (2012). Characterizing physicochemical changes of cookies baked in a commercial oven, Food Research International, 48, 249-256.

18. Zamora, M. C., Chirife, J., Roldán, D. (2006). On the nature of the relationship between water activity and \% moisture in honey, Food Control, $17,642-647$ 


\section{УТИЦАЈ ТЕМПЕРАТУРЕ И ВРЕМЕНА ПЕЧЕЊА НА КАРАКТЕРИСТИКЕ БЕЗГЛУТЕНСКОГ КЕКСА ОБОГАЋЕНОГ ТРОПОМ БОРОВНИЦЕ}

Бојана М. Шарић, Наташа М. Недељковић, Оливера Д. Шимурина, Младенка В. Песторић, Јована J. Кос, Анамарија И. Мандић, Маријана Б. Сакач, Љубиша Ћ. Шарић, Ђорђе Б. Псодоров, Александра Ч. Мишан

Универзитет у Новом Саду, Научни институт за прехрамбене технологије у Новом Саду, 21000 Нови Сад, Булевар цара Лазара бр. 1, Србија

Сажетак: Троп боровнице, настао као споредни производ приликом производње сока, је сушењем и млевењем прерађен у додатак који је искоришћен за формулацију новог безглутенског кекса са циљем унапређења његових нутритивних и антиоскидантних својстава. С обзиром на то да је познато да услови печења - температура и време, у великој мери утичу на квалитет крајњег производа, циљ рада био је да се оптимизују услови печења у циљу добијања производа најбољег технолошког квалитета.

Поређењем резултата печења на 160 и $170{ }^{\circ} \mathrm{C}$, у различитим временским интервалима, може се закључити следеће: разлика у условима печења не доводи до промене пречника производа (разлика мања од 1\%), правилнији облик производа добија се краћим печењем, чврстоћа производа је у корелацији са његовом влагом, активношћу воде, губитком влаге приликом печења и односом дужег и краћег пречника. Компоненте боје $\left(L^{*}, a^{*}\right.$ и $\left.b^{*}\right)$ горње и доње површине кекса указују да кекс није препечен ни једним од примењених третмана.

На основу добијених резултата, закључено је да се печењем безглутенског кекса обогаћеног тропом боровнице у трајању од 14 мин на температури од $170{ }^{\circ} \mathrm{C}$ добија производ оптималног квалитета.

Кључне речи: безглутенски кекс, троп боровнице, време печења, температура печења

Received: 12 February 2014

Accepted: 10 April 2014 